\title{
Shari'ah Perspective Ratio of Islamic Financing: Base Profit Rate vs Rule 78
}

\author{
Nurfadhlina Abdul Halim, Nadhirah Gazali, Wan Muhamad Amir W Ahmad, Mustafa Mamat
}

\begin{abstract}
In Malaysia, Islamic financing contract has various of concepts for example Bai Bithaman Ajil (BBA), AlIjarah Thumma Al-Bai (AITAB) and Musharakah. One of the model is used in calculating financing Islamic concept is called Rule 78. This model is widely used by Islamic finance/banking in Malaysia. However, there are lack of Shari'ah in this formulation based on parameter and also foundation of its formulation. Hence, an alternative model is more Shari'ah perspective is build, namely base pro trate (BPR). Therefore, the intention of this paper is to investigate the existing model and alternative model used by Islamic finance/banking that is Rule 78 and BPR, respectively based on Shari'ah perspective.

Index Terms - Base profit rate, profit rate, reference rate, Rule 78, shari'ah.
\end{abstract}

\section{INTRODUCTION}

Since 2011, almost 50 financial institutions including banks has been run Islamic banking operations. There are several financing concepts offered by Islamic banking such as murabahah, ijarah and Bai Bithaman Ajil (BBA) [7]. According to [2], Islamic banks are built based on two main factors, namely religious claims and profit. Hence, from financing activities the profit gained need to consider religious claims that is Shari'ah (Islamic Law) perspective. Therefore, the profit gained must avoided from the element such as riba (usury), gharar (uncertainty) and masyir (speculation). Unlike, conventional financing there are no law to follows to gain profit. Besides, according to [4], the concept used in the conventional financing is based on usury. is conventional financing system and Islamic financing system, but both of this system has difference rules to gain profit in financing. This is because Islamic financing activates not only focus on gain profit but also consider the relationship between humans and creators (Allah s.w.t) and as well as fellow human beings [11]. Therefore, Islamic concepts that used in Islamic finance/banking also need to give emphasizing on method used to gain profit based on Shari'ah perspective. This is because according to [1], although Islamic finance uses the concepts of financing organized by Shari'ah and is widely used in Malaysia. But

Revised Manuscript Received on July 10, 2019.

Nurfadhlina Abdul Halim, Faculty Science and Technology, Universiti Sains Islam Malaysia, Bandar Baru Nilai, 71800 Nilai, Negeri Sembilan, Malaysia.

Nadhirah Gazali, School of Informatics and Applied Mathematics, Universiti Malaysia Terengganu, 21030 Kuala Terengganu, Terengganu, Malaysia.

Wan Muhamad Amir W Ahmad, School of Dental Science, Universiti Sains Malaysia, 11800 Gelugor, Penang, Malaysia.

Mustafa Mamat, Faculty of Informatics and Computing, Universiti Sultan Zainal Abidin, Besut Campus, 22200 Kuala Terengganu, Terengganu, Malaysia. commercial banks, companies finance and cooperation

Hence, although Malaysia has dual financial system that

the methods used by the concept put forward by the Islamic financial system has drawn criticism from Islamic scholars, legal practitioners and consumers. This show that Islamic financing nowdays still using the method and parameter that is non-compliant toward Shari'ah. This argument also supported by finding by [8], the method and basis of the formation of the profit used in Islamic financing is in common with conventional financing. Therefore, it is the objective of this paper to compare basic formation of the existing method that is Rule 78 and alternative method in Islamic financing based on Shari'ah perspective.

\section{RULE 78 FORMULATION}

The formula is widely used in Islamic finance contract in Malaysia is known as Rule 78 is given in (1) [5].

$$
\begin{gathered}
V=P+\operatorname{Pr} T \\
V=P(1+r T)
\end{gathered}
$$

where $V, P, r$ and $T$ is total amount of financing contract, principal, profit rate and period (in years) respectively.

By using (1), the monthly periodic payment is calculated and given in (2).

$$
\begin{aligned}
& S=\frac{P(1+r T)}{n} \\
& S=\frac{V}{n}
\end{aligned}
$$

where $S$ and $n$ is monthly payment and number of periodic payment respectively.

In (1), it shows that the basic of formation is based on concept of simple interest, which is the principal plus the profit calculated based on the period $T$ to obtain the amount of simple interest. The simple interest actually applying the element of riba qardh, which is increase of the original principal imposed since the beginning of the contract until maturity of the loan [6]. This will cause in oppression against both parties. This is because the profit Rule 78 approach is determined based on the fixed profit rate from the beginning until maturity. Whereas profit should be according to the current economic situation. Fixed rate in profit are not permitted in Islam [11].

Besides, profit generated based on the profit rate. Profit rate is given in (3) [3].

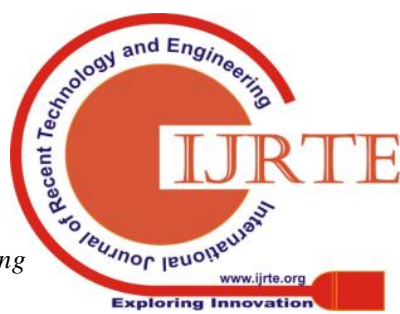




$$
r=w+x_{l}+x_{c}+O_{c}+i
$$

with $w, x_{l}, x_{c}, O_{c}$ and $i$ is reference rate, liquidity risk, credit risk, operating cost and profit margin, respectively.

This basic formation of profit rate used nowadays based on reference rate which is base rate (BR). BR is constructed based on two parameter which is benchmark cost of funds and Statutory Reserve Requirement (SRR) [3]. Benchmark cost of funds and the SRR are directly proportional to the overnight policy rate (OPR). OPR is the interest rate between banks and was carried out to ensure sufficient savings in the bank every day [12]. So, the transaction between the bank use OPR as interest rate whether the conventional bank or Islamic banks. However, when the money is used as commodities in a transaction, it falls under the definition of riba [11]. Thus, when the OPR affect BR, profit rate of Islamic finance directly have the elements of riba. Besides, BR is used for dual financing system, it show that there are no difference between parameter used in Islamic finance and conventional finance [9].

\section{ALTERNATIVE FORMULA OF ISLAMIC FINANCING}

An alternative model is known as a base profit rate (BPR) model. This formula construct for financing instrument based on deferred installment contract. This formula implies two components: principal payment and profit. Principal payment in BPR model is applied Shari'ah concept that is musyarakah mutanaqisah. While, determination of profit is based on current economic condition that is based on economic bubble size. BPR formula is given in (4) until (9).

First, we consider principal payment by customer done periodically through monthly payment is given in (4).

$$
a=\frac{P}{n}
$$

where $a, P, n$ is payment of principal for each period, principal and number of periodic payment respectively.

Secondly, we determine the profit based on rate of bubble size as profit rate alternative by using Generalized JohansenLedoit-Sornette (GJLS) model is given in (5), the formations of GJLS model can be refer to [10].

$$
\ln \left[p(t)-p_{1}=F_{L P P L}(t)\right.
$$

where $F_{L P P L}(t), p_{1}$ and $p(t)$ is economic bubble size, intrinsic value and price of a stock index respectively. Hence, bubble size rate (notation, $\hat{g}$ ) is given in (6).

$$
\hat{g}=\left(\frac{p(t)}{p_{1} n^{\prime}}-\frac{1}{n^{\prime}}\right) \times 100 \%
$$

where $n^{\prime}$ is number of periodic stock index data.

However, the profit rate in BPR model has maximum limit obtained from the opinion of scholars. Subject to maximum limit of $\hat{g} \leq \frac{33.33 \%}{12}$ and $\hat{g} \geq 0$, where the value of $33.33 \%$ can be referring to [10].

Lastly, the monthly payment of BPR model is given in (7).

$$
\begin{gathered}
S_{t}=a+U_{t} \\
S_{t}=a+\hat{g}(P-t a)
\end{gathered}
$$

The determination of amount (notation, $V$ ) of the Islamic financing instrument is commonly given in (8).

$$
\begin{gathered}
V=\sum_{t=1}^{n} S_{t} \\
V=\sum_{t=1}^{n}(a+\hat{g}(P-t a))
\end{gathered}
$$

The return on principal (notation, $U$ ) generated in (8) is given in (9).

$$
\begin{aligned}
& U=\sum_{t=1}^{n}(a+\hat{g}(P-t a))-P \\
& U=V-P
\end{aligned}
$$

\section{RESULTS AND DISCUSSION}

The empirical test on Rule 78 model and BPR model rate by using same data for comparison purposes as below:

Principal: RM45000.00

Tenure (years): 3

Tenure (months): 36

For Rule 78 model, the profit rate is $6 \%$ yearly. Table 1 shows the illustration execution by using Rule 78 model.

Table 1: Illustration execution by using Rule 78 model

\begin{tabular}{|c|c|c|c|c|}
\hline Period & $\begin{array}{c}\text { Periodical } \\
\text { Payment }\end{array}$ & $\begin{array}{c}\text { Profit } \\
\text { Amortisation }\end{array}$ & $\begin{array}{c}\text { Principal } \\
\text { Amortisation }\end{array}$ & $\begin{array}{c}\text { Remaining } \\
\text { Principal }\end{array}$ \\
\hline 0 & & & & 45000.00 \\
\hline 1 & 1475.00 & 486.49 & 988.51 & 44011.49 \\
\hline 2 & 1475.00 & 472.97 & 1002.03 & 43009.46 \\
\hline 3 & 1475.00 & 459.46 & 1015.54 & 41993.92 \\
\hline 4 & 1475.00 & 445.95 & 1029.05 & 40964.86 \\
\hline 5 & 1475.00 & 432.43 & 1042.57 & 39922.30 \\
\hline. &. &. &. &. \\
\hline. &. &. &. &. \\
\hline. &. &. &. &. \\
\hline 33 & 1475.00 & 54.05 & 1420.95 & 5243.92 \\
\hline 34 & 1475.00 & 40.54 & 1434.46 & 3809.46 \\
\hline 35 & 1475.00 & 27.03 & 1447.97 & 2361.49 \\
\hline 36 & 1475.00 & 13.51 & 1461.49 & 900.00 \\
\hline Total & 53100.00 & & & \\
\hline & & & & \\
\hline
\end{tabular}


Whereas, by using same data but difference determination of profit rate and profit evaluation. Table 3 shows the illustration execution by using BPR model.

First, we predict the bubble size by using GJLS model. We estimate the $\omega$ value by three consecutive price peaks. The best result is chosen based on MSE value. The results of the bubbles size as shown in Table 2 .

Table 2: Predicted bubbles size of KLCI, 1997 and 2008

\begin{tabular}{|c|c|c|c|}
\hline $\begin{array}{c}\text { Time } \\
\text { Interval }\end{array}$ & $\begin{array}{c}\text { Market } \\
\text { Value }\end{array}$ & $\begin{array}{c}\text { Intrinsic } \\
\text { Value }\end{array}$ & $\begin{array}{c}\text { Bubble } \\
\text { Size }\end{array}$ \\
\hline $28 / 08 / 1998-31 / 01 / 2008$ & 1445.03 & 580.60 & $864.43,67.17 \%$ \\
\hline
\end{tabular}

From Table 2, bubbles size rate for 10 years is $67.17 \%$. Hence, in (6), periodic bubble size rate is $0.56 \%$ from 1998 until 2008. This is because the results in Table 2 show that financial bubble usually happened every 10 years. This empirical test is used the data from 2006 until 2008. So, there are no changes of the bubble size value between that time.

Table 3: Illustration execution by using BPR model

\begin{tabular}{|c|c|c|c|c|c|}
\hline Period & $\begin{array}{c}\text { Principal } \\
\text { Amortisatio } \\
\mathrm{n}\end{array}$ & $\begin{array}{c}\text { Remaining } \\
\text { Principal }\end{array}$ & $\begin{array}{c}\text { Bubble } \\
\text { Size }\end{array}$ & $\begin{array}{c}\text { Profit } \\
\text { Cost }\end{array}$ & $\begin{array}{c}\text { Periodical } \\
\text { Payment }\end{array}$ \\
\hline 0 & & 45000.00 & & & \\
\hline 1 & 1250.00 & 43750.00 & 0.0056 & 245.00 & 1495.00 \\
\hline 2 & 1250.00 & 42500.00 & 0.0056 & 238.00 & 1488.00 \\
\hline 3 & 1250.00 & 41250.00 & 0.0056 & 231.00 & 1481.00 \\
\hline 4 & 1250.00 & 40000.00 & 0.0056 & 224.00 & 1474.00 \\
\hline 5 & 1250.00 & 38750.00 & 0.0056 & 217.00 & 1467.00 \\
\hline$\cdot$ & $\cdot$ &. &. &. &. \\
\hline$\cdot$ & $\cdot$ &. &. &. &. \\
\hline$\cdot$ & $\cdot$ &. &. &. &. \\
\hline 33 & 1250.00 & 3750.00 & 0.0056 & 21.00 & 1271.00 \\
\hline 34 & 1250.00 & 2500.00 & 0.0056 & 14.00 & 1264.00 \\
\hline 35 & 1250.00 & 1250.00 & 0.0056 & 7.00 & 1257.00 \\
\hline 36 & 1250.00 & 0.00 & 0.0056 & 0.00 & 1250.00 \\
\hline Total & & & & & 49410.00 \\
\hline
\end{tabular}

\section{CONCLUSION}

Islamic financing instrument are valued based on Rule 78 model. Rule 78 model was constructed by applying the simple interest concept which is non-compliance toward Shari'ah perspective because there are element of riba. Not only the concept, but parameter that used on determination profit value based on BR also non-compliance with the Shari'ah. This is because the determination of BR is directly proportional to the overnight policy rate (OPR). OPR have element of riba make overall profit evaluation also have the element of riba.

Hence, the alternative formula known as based profit rate (BPR) was built to meet Shari'ah perspective. From the empirical test towards alternative profit rate model, it is proved that the establishment of base profit rate (BPR) can be applied in the real world. The bubble size reflect the current economic condition, it is relevant as a proxy in BPR model. Besides, the maximum profit margin in this model is determined based on scholar opinion is to prevent any of contradiction opinion between ummah. This show that BPR model more Shari'ah-compliant because no element of ghabn fashisy in Islamic financing. It can be concluded that, this alternative model is more compliance towards Shari'ah rather than existing model because determination of the profit rate is transparent and clear.

\section{REFERENCES}

1. A. M. M. Ahmad Tarmidzi, Bay' Bithaman Ajil in house nancing as implemented by Malaysian financial institutions: A critical analysis of its procedures and application from the fiqh of view. Master thesis, Selangor: International Islamic University Malaysia, 2007.

2. Bank Muamalat, Perbandingan antara perbankan Islam dan konvensional. Available: http://www.muamalat.com.my/downloads/mediaroom/publications/al-muamalat-V03.pdf.

3. Bank Negara Malaysia, Laporan tahunan 2014. Available: http://www.bnm.gov.my/index.php?ch=bm_publication\&pg= bm_ar\&ac $=21 \& l a n g=b m$.

4. B. Gascoigne, History of capitalism. Available: http://www.historyworld.net.

5. I. A. Ghafar, Money, Islamic Banks and the Real Economy. Singapore: Cengage Learning, 2010.

6. T. Hadenan, and B. J. Tamkin, Untung dalam Sistem Perbankan Islam. Kuala Lumpur: Universiti Malaysia Press, 2006.

7. S. Haron, and W. A. Wan Nursofiza, Islamic Finance and Banking System. Kuala Lumpur: McGraw-Hill, 2009.

8. M. M. Hisyam, Nilai masa wang dalam skim perbankan Islam. Available: http://www.ikim.gov.my/index.php/ms/berita-harian/7610nilai-masa-wang-dalam-skim-perbankan-islam.

9. G. Nadhirah, A. H. Nurfadhlina, A. A. Mohd Asrul, W. A. Wan Muhammad Amir, M. Mustafa, A. Zailani, and M. Kasypi, "The alternative profit on shariah-compliant by using compounding theory," International Journal of Engineering and Technology, 7(2.14), 2018, pp. 39-42.

10. N. Gazali, N. A. Halim, and P. L. Ghazali, "Alternative profit rate shariah-compliant for Islamic banking," Journal of Physics: Conference Series, 890(1), 2017, pp. 1-6.

11. A. H. Nurfadhlina, Pemodelan matematik instrumen sewa-beli Islam alternative berkonsepkan perkongsian untung-rugi. $\mathrm{PhD}$ thesis, Selangor: Universiti Kebangsaan Malaysia, 2013.

12. A. R. Zaharuddin, Kenaikan OPR and BLR: kesan terhadap kita. Available: http://zaharuddin.net/senarai-lengkapartikel/3/1035-kenaikan-opr-a-blr \{ kesan-terhadap-kita.html. 